\title{
Source Apportionment of Particulate Matter in Urban Snowpack Using End-Member Mixing Analysis and Positive Matrix Factorization Model
}

\author{
Mikhail Y. Semenov*, Natalya A. Onishchuk, Olga G. Netsvetaeva and Tamara V. Khodzher
}

check for

updates

Citation: Semenov, M.Y.; Onishchuk, N.A.; Netsvetaeva, O.G.; Khodzher, T.V. Source Apportionment of Particulate Matter in Urban Snowpack Using End-Member Mixing Analysis and Positive Matrix Factorization Model. Sustainability 2021, 13, 13584. https://doi.org/ $10.3390 /$ su132413584

Academic Editor: David Patiño Vilas

Received: 3 November 2021

Accepted: 7 December 2021

Published: 8 December 2021

Publisher's Note: MDPI stays neutral with regard to jurisdictional claims in published maps and institutional affiliations.

Copyright: (c) 2021 by the authors. Licensee MDPI, Basel, Switzerland. This article is an open access article distributed under the terms and conditions of the Creative Commons Attribution (CC BY) license (https:// creativecommons.org/licenses/by/ $4.0 /)$.

\author{
Limnological Institute of Siberian Branch, Russian Academy of Sciences, Ulan-Batorskaya St. 3, 664033 Irkutsk, \\ Russia; onischuk@lin.irk.ru (N.A.O.); r431@lin.irk.ru (O.G.N.); khodzher@lin.irk.ru (T.V.K.) \\ * Correspondence: smu@mail.ru
}

\begin{abstract}
The aim of this study was to identify particulate matter (PM) sources and to evaluate their contributions to PM in the snowpack of three East Siberian cities. That was the first time when the PM accumulated in the snowpack during the winter was used as the object for source apportionment study in urban environment. The use of long-term integrated PM samples allowed to exclude the influence of short-term weather conditions and anthropogenic activities on PM chemistry. To ascertain the real number of PM sources and their contributions to air pollution the results of source apportionment using positive matrix factorization model (PMF) were for the first time compared to the results obtained using end-member mixing analysis (EMMA). It was found that $\mathrm{Si}, \mathrm{Fe}$ and Ca were the tracers of aluminosilicates, non-exhaust traffic emissions and concrete deterioration respectively. Aluminum was found to be the tracer of both fossil fuel combustion and aluminum production. The results obtained using EMMA were in good agreement with those obtained using PMF. However, in some cases, the non-point sources identified using PMF were the combinations of two single non-point sources identified using EMMA, whereas the non-point sources identified using EMMA were split by PMF into two single non-point sources. The point sources were clearly identified using both techniques.
\end{abstract}

Keywords: particulate matter; snowpack; Eastern Siberia; sources; tracers; EMMA; PMF

\section{Introduction}

The associations between air pollution with particulate matter (PM) and adverse human health effects have been well documented [1,2]. Deposition of anthropogenic particulate matter on soil, vegetation and especially on impervious surfaces causes the pollution of surface waters that affects the terrestrial and aquatic organisms [3-6]. The latter is especially important for urban areas in Lake Baikal watershed characterized by a long cold winter, resulting in accumulation of large amounts of pollutants in urban snowpack $[7,8]$ and their explosive release into watercourses during the snowmelt period [9-11]. To reduce the pollution load on both terrestrial and aquatic ecosystems, the pollution sources should be identified. The most problem of identification of pollutant sources is the lack or absence of emission composition data called source profiles [12]. Without data on source profiles, the source identification is somewhat speculative, because the essence of identification is to compare the ratios of pollutant concentrations in the source emission called source tracers with those in some environmental compartment. The lack of the data on source profiles is particularly important for the Lake Baikal area. For this reason, the overwhelming number of studies devoted to identification of pollutant sources in this area was based on backward trajectories modeling $[13,14]$. The only profiles of polycyclic aromatic hydrocarbons (PAHs) from several source types are available in the Lake Baikal watershed [15-17].

To avoid difficulties concerned with obtaining the source profiles, the multivariate data analysis methods such as principal component analysis [18,19], cluster analysis [20,21], and 
factor analysis $[18,22]$ are used for source identification and apportionment. Multivariate methods do not require source profiles. They use an orthogonal transformation to convert a set of observations of possibly correlated variables (tracers) into a set of values of linearly uncorrelated variables called principal components or factors. Each factor is assumed to represent a source [23-27], characterized by a certain group of chemicals (source profile).

The most widely used multivariate data analysis method is positive matrix factorization (PMF) [28]. PMF allows to obtain source profiles and to evaluate source contributions to pollution. The selection of chemical species that are used as source tracers is crucial for source apportionment using PMF. According to European guide on air pollution source apportionment with receptor models [29] the chemical species to include in the analysis should be selected according to the study objectives, the site characteristics and expected sources, considering the available human, technical and financial resources. Alternatively, the set of tracers should consist of chemical species that represents most of the particulate mass such as water-soluble salts, insoluble particulates, organic matter constitutes plus a number of elements whose absolute and relative concentrations or specific ratios are used to identify sources [29]. To meet these criteria, many different chemical analyses should be performed; therefore, the species characterized by similar chemical properties are usually used as tracers for simplicity. These can be major ions [30,31], organic substances [32-35], metals [36,37] or contributions of different PM fractions to total PM mass [38]. However, regardless of the merits of PMF, the results obtained using this model may be misleading because the reconstructed source profiles may be combinations of several real source profiles, or may not exist at all $[39,40]$. One more difficulty with using PMF is the need for comprehensive information on PM composition: The greater the input data the higher the consistency between the real and modelled source profiles and source contributions to pollution [41]. Traditionally, the time-series and spatial data on chemical composition of PM are used for source apportionment. Thus, the most common way to improve the data quality is to increase the temporal $[36,42,43]$ or spatial $[44,45]$ resolution of PM sampling. In recent times, the online measurement of aerosol composition using high-resolution time-of-flight aerosol mass spectrometers is used to obtain high-quality input data for PMF [46,47].

The aim of this study was to apportion sources of PM deposited in the snowpack using the PMF model. To validate the source profiles obtained using PMF, they were compared to chemical composition of natural and anthropogenic materials characteristic for this area. To validate the source contributions to snow PM, the end-member mixing analysis (EMMA) previously used in hydrological studies $[48,49]$ was applied. The essence of method is to determine the dimensionality of air/snow quality data using small number of conservative source tracers.

\section{Materials and Methods}

\subsection{Study Area}

The study was conducted in three Southeastern Siberian cities, namely Irkutsk, Shelekhov and Slyudyanka, located near the Lake Baikal (Figure 1) in 2018-2020. The study area is characterized by long, cold winters lasting 4-5 months (November-February). During this time, the Siberian anticyclone stops Atlantic and East Asian air from advancing into Eastern Siberia, leading to prolonged frosts and fair weather in the Lake Baikal area. The mean winter air temperatures are about -15 to -20 degrees Celsius $\left({ }^{\circ} \mathrm{C}\right)$.

Irkutsk is an administrative center of Irkutsk Region and home to almost 700,000 people, whereas Shelekhov and Slyudyanka are much less densely populated cities (50,000 and 19,000 people respectively). There are numerous anthropogenic sources, such as traffic emissions, oil-fired and coal-fired central and residential heating boilers, wood stoves, cement and asphalt plants, woodworking plants, etc., located in each city. The industrial emission sources such as aluminum plant, cable factory, silica manufacturing plant, etc. are located only in Shelekhov city. There are no industrial sources in Irkutsk city; however, it is situated downwind from the large Angarsk petroleum refinery, thus the snow pollution 
due to refinery operations and stationary fuel combustion is also possible. Slyudyanka city, located on the southeastern shore of lake Baikal, was characterized by the lowest level of economic activity among the studied cities.

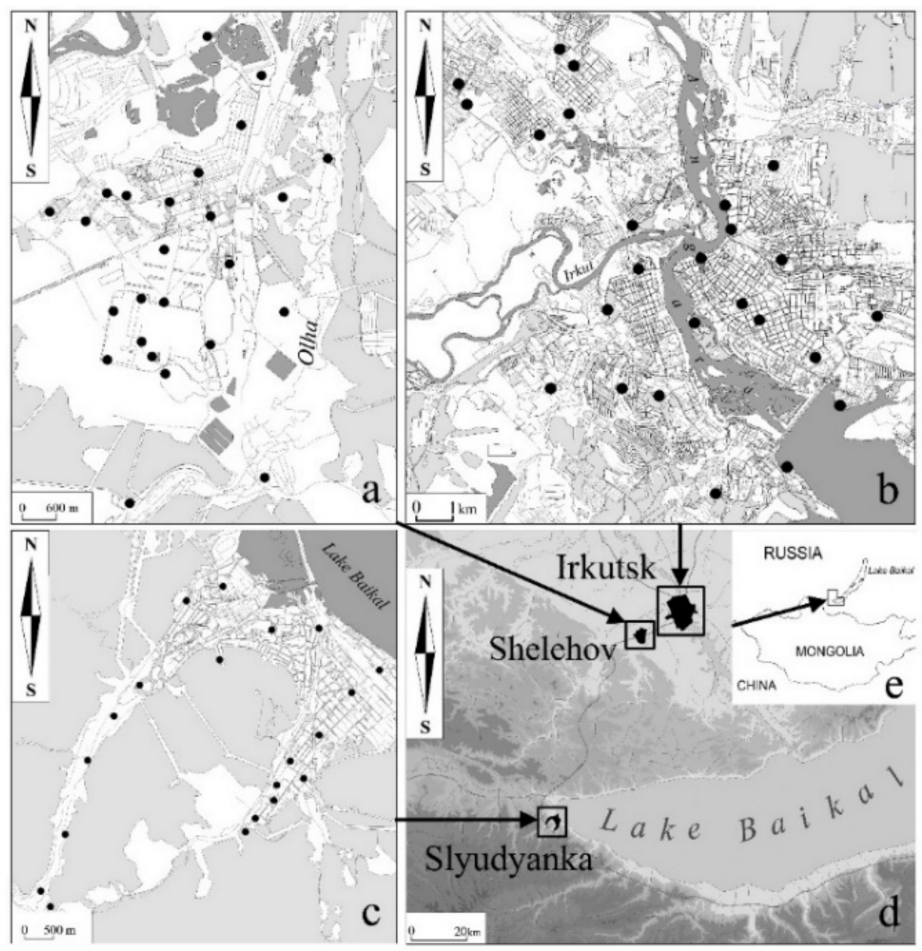

Figure 1. The location of Shelekhov (a), Irkutsk (b) and Slyudyanka (c) cities in Baikal region (d) and in Central Asia (e); black dots are sampling points.

\subsection{Sampling and Chemical Determinations}

Snowpack was used as the study object because it is a unique natural archive of particles deposited from the atmosphere [50], which provides the time-weighted information on aerosol composition and abundance of anthropogenic PM sources without using expensive up-to-date equipment. The use of PM deposited in the snowpack instead of PM dispersed in air allows for the exclusion of the influence of short-term weather conditions and anthropogenic activities on PM chemistry in whiner. The snow was sampled in February before the snowmelt. The height of the snowpack varied from about $30 \mathrm{~cm}$ to almost $1.5 \mathrm{~m}$. Snow samples were collected over the whole depth of the snow layer. The weight of snow samples varied from 0.5 to $1.5 \mathrm{~kg}$. Two hundred and ten samples were collected in total at three sites during three years: Seventy five samples in Irkutsk, 75 samples in Shelekhov and 60 samples in Slyudyanka. Snow samples were stored in plastic bags in refrigerator at negative temperatures prior to analysis. The melt water was filtered through $47 \mathrm{~mm}$ Whatman ${ }^{\circledR}$ nitrocellulose membrane filters with pore size of $0.45 \mu \mathrm{m}$. To avoid misleading conclusions on composition of PM deposited in snow, the concentrations of elements that form soluble salts (N, $\mathrm{Cl}, \mathrm{P}, \mathrm{S})$ were not measured because soluble PM may dissolve during snow melting procedure.

After meltwater filtration, filters containing insoluble particulate matter were dried. The weight of dry PM samples varied from 0.002 to $0.03 \mathrm{~g}$. The average weight of samples collected in Slyudyanka $(0.017 \mathrm{~g})$ were higher than the average weight of samples collected in Irkutsk $(0.007 \mathrm{~g})$ and Shelekhov $(0.009 \mathrm{~g})$. The differences in weight of dry samples among the cities were conditioned by the differences in amounts of snow. To compare the levels of air pollution in the three cities, the element contents in dry samples were normalized to precipitation amounts and presented as element mass per unit of snow meltwater volume. The dry samples were than subjected to microwave-assisted digestion prior to analysis. A closed-vessel microwave-assisted reaction system was used. Particle 
samples in filters were placed into the Teflon digestion vessels. Seven milliliters of $\mathrm{HNO}_{3}$, $2 \mathrm{~mL} \mathrm{HCl}$ and $1 \mathrm{~mL} \mathrm{HF}$ were added to each vessel, immersing the sample [51]. The vessels were closed and heated in the microwave oven following a three-step digestion program. The digestate was cooled and then diluted to $100 \mathrm{~mL}$.

The concentrations of $\mathrm{Si}, \mathrm{Al}, \mathrm{Fe}, \mathrm{Ca}, \mathrm{K}, \mathrm{Mn}, \mathrm{Cr}, \mathrm{Ti}, \mathrm{Ni}, \mathrm{Cu}, \mathrm{Zn}, \mathrm{Sr}$ and $\mathrm{Pb}$ in digestate were measured using an Agilent 7500 inductively coupled plasma mass spectrometer (ICP-MS). All samples were spiked with internal standards to control the quality of measurement. The mass spectrometer was calibrated at seven concentration levels $(0.2,0.5,1,2,5,10$, and $20 \mu \mathrm{g} / \mathrm{L})$ prior to analysis. The multi-element standard solutions ICP-MS68A-A and ICP-MS-68A-B were used for calibration. Detection limits varied from 0.03 (for $\mathrm{Ni}$ and $\mathrm{V}$ ) to $0.2 \mu \mathrm{g} / \mathrm{L}$ (for $\mathrm{Al}$ and $\mathrm{Fe}$ ). Measurement precision was in the range $2 \%$ to $7 \%$ and measurement accuracy was in the range $2.7 \%$ to $13.4 \%$.

\subsection{Data Processing}

The source apportionment analysis was carried out by means of the PMF 5 software package using data on chemical composition of snow particulate matter as input. PMF model decomposes a matrix of chemical composition dataset into two matrices describing as factor profiles and factor contributions [36]:

$$
\mathrm{X}=\mathrm{G} \cdot \mathrm{F}+\mathrm{E},
$$

where $\mathrm{X}$ is the matrix of the chemical species concentrations in samples, $\mathrm{G}$ is a matrix of the contribution to the samples of sources, $\mathrm{F}$ is a matrix of source profiles and $\mathrm{E}$ is the matrix of the residuals, which are the difference between the measured concentrations $(X)$ and the values reconstructed from the model $(\mathrm{G} \times \mathrm{F})$.

The mass conservation between the species concentrations in object of study and source emissions can also be written in index notation:

$$
\chi_{i j}=\sum_{k=1}^{p} g_{i k} f_{k j}+e_{i j}
$$

where $\chi_{i j}$ is the concentration of species $j$ measured in sample $i, p$ is the number of factors contributing to the samples, $f_{k j}$ is the concentration of species $j$ in factor profile $k, g_{i k}$ is the relative contribution of factor $k$ to sample $i$ and $e_{i j}$ is error of the PMF model for the species $j$ measured in sample $i$.

The main aim of PMF is to minimize the sum of squares of standardized residuals or $\mathrm{Q}$ : The lower the $\mathrm{Q}$ the lower the discrepancy between measured and reconstructed concentrations of chemical species. Determination of the uncertainty for each of the measured data is the pre-requisite for the application of PMF. Uncertainties associated with measured chemical species were determined by adding the values of one-third of detection limit (DL) to the measured analytical uncertainty [29]. Concentrations of all the measured elements were much higher than DLs in datasets from all three sites. An extra 10\% modeling uncertainty was introduced to account for other possible errors not considered in the uncertainty assessment [43]. Three-years pooled datasets from three sites were analyzed independently, as the sources affecting those sites were expected to be different to some extent. Two to seven factors were severally run to determine the appropriate number of source factors. The final number of factors was decided on the base of their physical interpretability [52]. To improve the obtained solutions the model parameter called $\mathrm{F}_{\text {peak }}$ was applied. $\mathrm{F}_{\text {peak }}$ controls the rotation in PMF by adding and/or subtracting the rows and columns of $\mathrm{F}$ and $\mathrm{G}$ matrices from each other depending on the sign of the $F_{\text {peak }}$ value. Positive $F_{\text {peak }}$ values sharpen the F-matrix and smear the G-matrix; negative $\mathrm{F}_{\text {peak }}$ values smear the F-matrix and sharpen the G-matrix.

Unfortunately, there are no clear rules to determine the number of factors that should be retained in PMF analysis, as well as there is no possibility to compare the source profiles reconstructed by PMF with the real ones. Therefore, the possible sources were also identified using the end-member mixing approach [48]. The identification procedure was 
based on plotting the samples on mixing diagram using the values of source tracers as co-ordinates. The chemical species concentration ratios were used as tracers, because the element concentrations in source exhaust and snow have different units of measurement. The chemical species used for calculating the tracer ratios had to meet three criteria: (1) Species had to be uncorrelated or negatively correlated with the other species, because positively correlated species have a common source [48]; (2) species had to be characterized by high concentrations in urban snowpack; (3) tracers had to exhibit marked differences in concentrations across the different sources. Sample points characterized by extreme coordinate values (that still fall within 1.5 times the interquartile range of data along the axes) were considered as candidates for PM sources [49,53,54]. The chemical composition of such samples was assumed to originate from one type of anthropogenic waste. The rule used to choose the right candidate samples which are most suitable as the sources was to determine whether most samples could be tightly bound by a tetrahedron whose vertices are sources. One more EMMA rule was that the number of sources was one more than the number of tracers.

\section{Results and Discussion}

\subsection{Chemical Composition of Particulate Matter}

Thirteen elements ( $\mathrm{Al}, \mathrm{Si}, \mathrm{K}, \mathrm{Ca}, \mathrm{Ti}, \mathrm{Cr}, \mathrm{Mn}, \mathrm{Fe}, \mathrm{Ni}, \mathrm{Cu}, \mathrm{Zn}, \mathrm{Sr}, \mathrm{Pb}$ ), of which concentrations were higher than detection limits in most of the particulate matter samples, were selected as candidate tracers for source identification. The highest concentrations of most of the measured elements were observed in Irkutsk city and the lowest concentrations were observed in Shelekhov city (Table 1).

Table 1. Basic statistical parameters of chemical composition of insoluble particulate matter, $\mu \mathrm{g} / \mathrm{L}$.

\begin{tabular}{|c|c|c|c|c|c|c|c|c|c|c|c|c|c|}
\hline Parameter & Al & $\mathrm{Si}$ & $\mathbf{K}$ & $\mathrm{Ca}$ & $\mathrm{Ti}$ & $\mathrm{Cr}$ & Mn & $\mathrm{Fe}$ & $\mathrm{Ni}$ & $\mathrm{Cu}$ & $\mathrm{Zn}$ & $\mathrm{Sr}$ & $\mathrm{Pb}$ \\
\hline & \multicolumn{13}{|c|}{ Irkutsk } \\
\hline Min & 2371 & 4381 & 97.8 & 210 & 38.8 & 1.25 & 5.90 & 405 & 1.17 & 3.01 & 2.87 & 2.51 & 0.84 \\
\hline 25th & 3575 & 7882 & 287 & 578 & 77.8 & 2.54 & 13.94 & 923 & 3.48 & 5.87 & 7.79 & 11.1 & 1.77 \\
\hline Median & 4424 & 10,934 & 549 & 1288 & 167 & 4.85 & 36.33 & 1723 & 7.00 & 9.04 & 16.0 & 21.9 & 2.86 \\
\hline 75th & 5304 & 14,667 & 815 & 2372 & 271 & 9.14 & 61.83 & 3932 & 14.4 & 17.6 & 27.9 & 47.5 & 5.44 \\
\hline Max & 7205 & 23,915 & 1964 & 16,457 & 632 & 24.19 & 137.94 & 7792 & 48.0 & 39.2 & 84.5 & 163 & 12.7 \\
\hline Mean & 4516 & 11,341 & 607 & 1858 & 187 & 6.45 & 42.26 & 2515 & 10.4 & 13.0 & 21.5 & 35.2 & 3.91 \\
\hline \multirow[t]{2}{*}{ STD * } & 1229 & 4069 & 409 & 2557 & 133 & 5.32 & 33.83 & 1973 & 9.67 & 9.90 & 18.0 & 36.3 & 2.90 \\
\hline & \multicolumn{13}{|c|}{ Shelekhov } \\
\hline Min & 4002 & 2727 & 35.1 & 122 & 15.3 & 1.49 & 2.95 & 176 & 0.67 & 1.47 & 2.51 & 0.93 & 0.88 \\
\hline 25 th & 9760 & 6801 & 124 & 337 & 30.5 & 2.99 & 8.05 & 686 & 3.70 & 2.83 & 8.40 & 2.39 & 3.47 \\
\hline Median & 12,772 & 10,613 & 314 & 749 & 72.3 & 3.35 & 16.5 & 1026 & 5.02 & 5.56 & 16.2 & 8.10 & 4.27 \\
\hline 75 th & 15,933 & 12,720 & 444 & 944 & 113 & 4.58 & 23.9 & 1404 & 7.58 & 9.76 & 22.5 & 12.2 & 6.21 \\
\hline Max & 21,543 & 15,391 & 664 & 2025 & 258 & 7.99 & 95.6 & 4885 & 13.5 & 17.9 & 31.4 & 50.8 & 8.64 \\
\hline Mean & 12,221 & 9919 & 295 & 777 & 84.9 & 3.87 & 20.7 & 1201 & 5.63 & 6.32 & 15.3 & 10.2 & 4.65 \\
\hline \multirow[t]{2}{*}{ STD } & 4801 & 3491 & 180 & 492 & 59.8 & 1.72 & 19.5 & 955 & 2.93 & 4.07 & 8.75 & 11.0 & 2.09 \\
\hline & \multicolumn{13}{|c|}{ Slyudyanka } \\
\hline Min & 587 & 997 & 41.5 & 45.0 & 7.62 & 0.24 & 0.95 & 70.7 & 0.48 & 0.59 & 0.50 & 0.34 & 0.25 \\
\hline 25th & 3704 & 5977 & 261 & 1587 & 106 & 2.39 & 20.6 & 1098 & 3.20 & 6.66 & 6.70 & 27.9 & 1.63 \\
\hline Median & 4723 & 7133 & 416 & 4481 & 122 & 4.48 & 36.0 & 1775 & 5.02 & 11.2 & 9.30 & 84.2 & 2.11 \\
\hline 75th & 5478 & 11,079 & 548 & 17,720 & 222 & 6.11 & 59.2 & 3215 & 7.34 & 22.9 & 17.3 & 119 & 3.80 \\
\hline Max & 7055 & 15,148 & 744 & 48,912 & 283 & 9.08 & 97.0 & 4210 & 9.92 & 30.9 & 24.1 & 170 & 6.15 \\
\hline Mean & 4686 & 8123 & 416 & 8947 & 149 & 4.46 & 43.0 & 2130 & 5.23 & 14.6 & 11.5 & 76.9 & 2.72 \\
\hline STD & 1532 & 3724 & 183 & 11,077 & 82.1 & 2.69 & 27.2 & 1218 & 2.74 & 9.77 & 7.06 & 52.2 & 1.62 \\
\hline
\end{tabular}

* Standard deviation.

The high level of snow pollution in Irkutsk was undoubtedly conditioned by its high population density, which is one order of magnitude higher than in Shelekhov. Silicon was the most abundant pollutant in Irkutsk city snowpack. The highest concentrations of heavy metals such as $\mathrm{Ti}, \mathrm{Cr}, \mathrm{Mn}, \mathrm{Fe}, \mathrm{Ni}$ and $\mathrm{Zn}$ were also observed in Irkutsk. 
The low level of snow pollution in Shelekhov city was due to both low population density and city location upwind of the industrial zone. Nevertheless, the influence of industrial sources in Shelekhov city was clearly apparent in high concentrations of $\mathrm{Al}$ and $\mathrm{Pb}$ in airborne $\mathrm{PM}$.

The elemental composition of PM in snowpack of Slyudyanka city was characterized by distinctly different levels of different pollutants. That was probably due to local meteorological conditions. Slyudyanka is located away from regional northwest air mass transfer (from Angara River valley towards to Selenga River delta) and surrounded by mountains that favors the prevalence of local and circum-Baikal winds transporting pollutants from one costal area to another [40]. The average concentrations of $\mathrm{Ca}, \mathrm{Ti}, \mathrm{Cu}, \mathrm{Sr}$ in Slyudyanka were highest, whereas the concentrations of $\mathrm{Si}, \mathrm{Ni}, \mathrm{Zn}, \mathrm{Pb}$ were lowest among the three cities studied.

\subsection{Identification of Pollution Sources and Their Tracers Using Correlation Analysis and End-Member Mixing Approach}

As it is clear from Table 2, there are six chemical species ( $\mathrm{Al}, \mathrm{Si}, \mathrm{Fe}, \mathrm{Ca}, \mathrm{Ni}$ and $\mathrm{Zn}$ ) that do not correlate with each other and with most of the other elements, thus are applicable for source apportionment (Table 2). Aluminum, silicon, iron and calcium were also characterized by high concentrations in snow particulate matter and thus could be used for calculating the tracer ratios of predominant pollution sources. The absence of correlation between $\mathrm{Al}, \mathrm{Si}, \mathrm{Fe}, \mathrm{Ca}$ and the trace elements is probably due to the fact that elements most abundant in Earth's crust are characterized by distinctly different proportions in natural and anthropogenic particulate matter, whereas concentrations of trace elements in emissions from different sources are similar. To identify PM sources and their tracers, all possible mixing diagrams that use ratios of $\mathrm{Al}, \mathrm{Si}, \mathrm{Fe}$ and $\mathrm{Ca}$ concentrations as coordinates were generated. Concentrations of $\mathrm{Si}$, Fe and $\mathrm{Ca}$ normalized to concentration of $\mathrm{Al}$, as well as concentrations of $\mathrm{Al}, \mathrm{Fe}$ and $\mathrm{Ca}$ normalized to concentration of $\mathrm{Si}$ were finally chosen as tracers of emission sources, because the use of these tracers allowed to bound the most of PM samples by a tetrahedron whose vertices are sources (Figures 2 and 3).

The particulate matter characterized by highest $\mathrm{Ca} / \mathrm{Al}$ and $\mathrm{Ca} / \mathrm{Si}$ ratios in Irkutsk and Shelekhov cities (Table 3) was probably originated from concrete deterioration (weathering and sanding) because building materials are the most probable Ca sources in urban environments [55]. It is known that the concentration of $\mathrm{Ca}$ in Portland cement is up to $40 \%$ [56]. The $\mathrm{Ca} / \mathrm{Al}$ and $\mathrm{Ca} / \mathrm{Si}$ ratios in particulates from Slyudyanka city were one order of magnitude higher than those in PM from Irkutsk and Shelekhov cities. That probably indicated a different Ca source, such as marble wastes stored in the Pereval marble quarry and its surroundings [57].

The particulate matter characterized by highest $\mathrm{Fe} / \mathrm{Al}$ and $\mathrm{Fe} / \mathrm{Si}$ ratios was probably originated from non-exhaust traffic emissions generated as a result of wearing down of car brakes, clutches, tires and road surfaces [58,59]. Diesel exhausts may also be the source of Fe; however, the Fe concentration in diesel soot $[60,61]$ is much lower than Fe concentration in brake linings [59]. Additionally, particles resulted from wearing down car brakes and clutches are much heavier than submicron and ultrafine metal-bearing soot particles typical for emission from diesel engines. Thus, non-exhaust traffic emissions should be the primary PM source in an urban environment, whereas the traffic exhaust should be the secondary one. The high Fe/Al and Fe/Si ratios observed in Slyudyanka were partly due to non-exhaust emissions of rail vehicles, because the city is stretched along the Trans-Siberian Railway.

The highest $\mathrm{Si} / \mathrm{Al}$ and the lowest $\mathrm{Al} / \mathrm{Si}$ ratios are typical for natural aluminosilicates, like sand applied on snow- and ice-covered roads to increase friction and improve road safety.

The excavation and construction activities could be the minor Si sources in winter.

The lowest $\mathrm{Ca} / \mathrm{Al}, \mathrm{Fe} / \mathrm{Al}, \mathrm{Si} / \mathrm{Al}$ ratios and the highest $\mathrm{Al} / \mathrm{Si}$ ratios in snow $\mathrm{PM}$ observed in Shelekhov city (Table 3) were definitely due to enrichment of PM with Al-bearing particles originated from emission of aluminum smelter [62,63]. Al-bearing particulates 
could pass through the scrubbers of aluminum plant due to equipment ageing or malfunction. One more possible source of $\mathrm{Al}$ could be the vaporization of sodium tetrafluoroaluminate at aluminum plant, its release into the atmosphere and subsequent deposition onto atmospheric particles $[64,65]$.

The lowest $\mathrm{Ca} / \mathrm{Al}, \mathrm{Fe} / \mathrm{Al}, \mathrm{Si} / \mathrm{Al}$ ratios and highest $\mathrm{Al} / \mathrm{Si}$ ratios in snow $\mathrm{PM}$ observed in Irkutsk and Slyudyanka cities were due to fossil fuel combustion [40]. The values of $\mathrm{Si} / \mathrm{Al}$ and $\mathrm{Al} / \mathrm{Si}$ ratios typical for fuel combustion were several times higher and lower than $\mathrm{Si} / \mathrm{Al}$ and $\mathrm{Al} / \mathrm{Si}$ values typical for aluminum production, respectively.

Table 2. Correlation matrices (Pearson coefficients) for 13 elements in particulate matter.

\begin{tabular}{|c|c|c|c|c|c|c|c|c|c|c|c|c|c|}
\hline & Al & Si & $\mathbf{K}$ & $\mathrm{Ca}$ & $\mathrm{Ti}$ & $\mathrm{Cr}$ & Mn & $\mathrm{Fe}$ & $\mathrm{Ni}$ & $\mathrm{Cu}$ & $\mathrm{Zn}$ & $\mathrm{Sr}$ & $\mathrm{Pb}$ \\
\hline & & & & & & & kutsk & & & & & & \\
\hline $\mathrm{Al}$ & 1 & & & & & & & & & & & & \\
\hline $\mathrm{Si}$ & $0.49 *$ & 1 & & & & & & & & & & & \\
\hline $\mathrm{K}$ & 0.48 & 0.68 & 1 & & & & & & & & & & \\
\hline $\mathrm{Ca}$ & 0.01 & 0.10 & 0.49 & 1 & & & & & & & & & \\
\hline $\mathrm{Ti}$ & 0.46 & 0.56 & 0.94 & 0.47 & 1 & & & & & & & & \\
\hline $\mathrm{Cr}$ & 0.33 & 0.29 & 0.68 & 0.48 & 0.84 & 1 & & & & & & & \\
\hline Mn & 0.40 & 0.56 & 0.88 & 0.70 & 0.93 & 0.80 & 1 & & & & & & \\
\hline $\mathrm{Fe}$ & 0.35 & 0.49 & 0.87 & 0.50 & 0.95 & 0.84 & 0.97 & 1 & & & & & \\
\hline $\mathrm{Ni}$ & 0.20 & 0.22 & 0.48 & 0.82 & 0.48 & 0.89 & 0.77 & 0.82 & 1 & & & & \\
\hline $\mathrm{Cu}$ & 0.23 & 0.31 & 0.46 & 0.72 & 0.75 & 0.81 & 0.78 & 0.84 & 0.84 & 1 & & & \\
\hline $\mathrm{Zn}$ & 0.19 & 0.29 & 0.68 & 0.81 & 0.50 & 0.47 & 0.81 & 0.81 & 0.81 & 0.82 & 1 & & \\
\hline $\mathrm{Sr}$ & 0.27 & 0.33 & 0.68 & 0.86 & 0.79 & 0.80 & 0.49 & 0.85 & 0.89 & 0.86 & 0.90 & 1 & \\
\hline $\mathrm{Pb}$ & 0.26 & 0.33 & 0.71 & 0.77 & 0.81 & 0.84 & 0.82 & 0.43 & 0.88 & 0.95 & 0.84 & 0.91 & 1 \\
\hline
\end{tabular}

Shelekhov

\begin{tabular}{|c|c|c|c|c|c|c|c|c|c|c|c|c|c|}
\hline \\
\hline $\mathrm{Al}$ & 1 & & & & & & & & & & & & \\
\hline $\mathrm{Si}$ & -0.34 & 1 & & & & & & & & & & & \\
\hline K & 0.29 & 0.11 & 1 & & & & & & & & & & \\
\hline $\mathrm{Ca}$ & 0.46 & 0.05 & 0.82 & 1 & & & & & & & & & \\
\hline $\mathrm{Ti}$ & 0.23 & 0.05 & 0.90 & 0.73 & 1 & & & & & & & & \\
\hline $\mathrm{Cr}$ & 0.27 & 0.14 & 0.77 & 0.77 & 0.89 & 1 & & & & & & & \\
\hline $\mathrm{Mn}$ & 0.14 & -0.05 & 0.71 & 0.49 & 0.91 & 0.88 & 1 & & & & & & \\
\hline $\mathrm{Fe}$ & 0.12 & -0.02 & 0.73 & 0.44 & 0.92 & 0.88 & 0.99 & 1 & & & & & \\
\hline $\mathrm{Ni}$ & 0.26 & 0.07 & 0.50 & 0.65 & 0.83 & 0.94 & 0.88 & 0.88 & 1 & & & & \\
\hline $\mathrm{Cu}$ & 0.36 & 0.06 & 0.72 & 0.88 & 0.78 & 0.87 & 0.69 & 0.50 & 0.79 & 1 & & & \\
\hline $\mathrm{Zn}$ & 0.58 & -0.17 & 0.52 & 0.73 & 0.50 & 0.72 & 0.49 & 0.43 & 0.79 & 0.84 & 1 & & \\
\hline $\mathrm{Sr}$ & 0.15 & -0.13 & 0.71 & 0.58 & 0.90 & 0.86 & 0.98 & 0.98 & 0.87 & 0.73 & 0.47 & 1 & \\
\hline $\mathrm{Pb}$ & 0.22 & 0.08 & 0.48 & 0.41 & 0.63 & 0.80 & 0.69 & 0.72 & 0.92 & 0.67 & 0.73 & 0.70 & 1 \\
\hline
\end{tabular}

\begin{tabular}{|c|c|c|c|c|c|c|c|c|c|c|c|c|c|}
\hline & \multicolumn{13}{|c|}{ Slyudyanka } \\
\hline $\mathrm{Al}$ & 1 & & & & & & & & & & & & \\
\hline $\mathrm{Si}$ & 0.53 & 1 & & & & & & & & & & & \\
\hline $\mathrm{K}$ & 0.68 & 0.51 & 1 & & & & & & & & & & \\
\hline $\mathrm{Ca}$ & 0.17 & -0.14 & 0.32 & 1 & & & & & & & & & \\
\hline $\mathrm{Ti}$ & 0.76 & 0.72 & 0.69 & -0.27 & 1 & & & & & & & & \\
\hline $\mathrm{Cr}$ & 0.73 & 0.77 & 0.47 & -0.33 & 0.92 & 1 & & & & & & & \\
\hline Mn & 0.65 & 0.49 & 0.73 & -0.14 & 0.94 & 0.82 & 1 & & & & & & \\
\hline $\mathrm{Fe}$ & 0.60 & 0.48 & 0.65 & -0.20 & 0.93 & 0.86 & 0.98 & 1 & & & & & \\
\hline $\mathrm{Ni}$ & 0.60 & 0.58 & 0.39 & -0.27 & 0.82 & 0.91 & 0.78 & 0.86 & 1 & & & & \\
\hline $\mathrm{Cu}$ & 0.45 & 0.42 & 0.10 & -0.11 & 0.53 & 0.74 & 0.48 & 0.61 & 0.88 & 1 & & & \\
\hline $\mathrm{Zn}$ & 0.52 & 0.42 & 0.54 & -0.33 & 0.82 & 0.75 & 0.80 & 0.84 & 0.83 & 0.61 & 1 & & \\
\hline $\mathrm{Sr}$ & 0.26 & -0.10 & 0.39 & 0.65 & 0.18 & 0.16 & 0.38 & 0.39 & 0.33 & 0.47 & 0.27 & 1 & \\
\hline $\mathrm{Pb}$ & 0.38 & 0.29 & 0.46 & -0.36 & 0.72 & 0.64 & 0.73 & 0.78 & 0.73 & 0.52 & 0.94 & 0.30 & 1 \\
\hline
\end{tabular}

* Bold font reflects weak positive and negative correlation. 
a

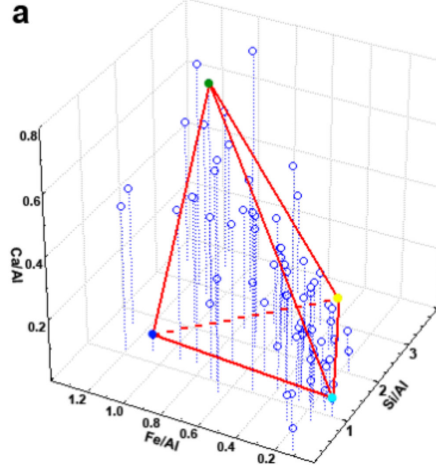

C

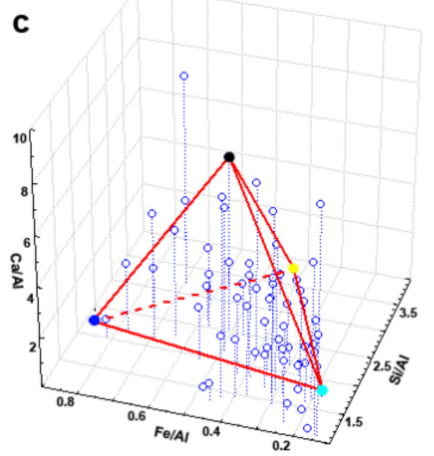

b
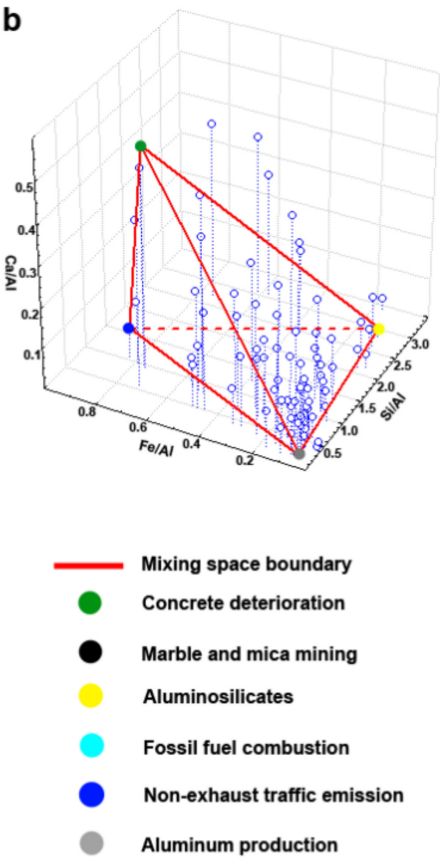

Figure 2. Diagrams illustrating the mixing of PM from different sources in snowpack in Irkutsk (a), Shelekhov (b) and Slyudyanka (c) cities using concentrations of Si, Fe and Ca normalized to concentration of $\mathrm{Al}$ as tracers; empty circles are snow samples, colored circles are emission sources.
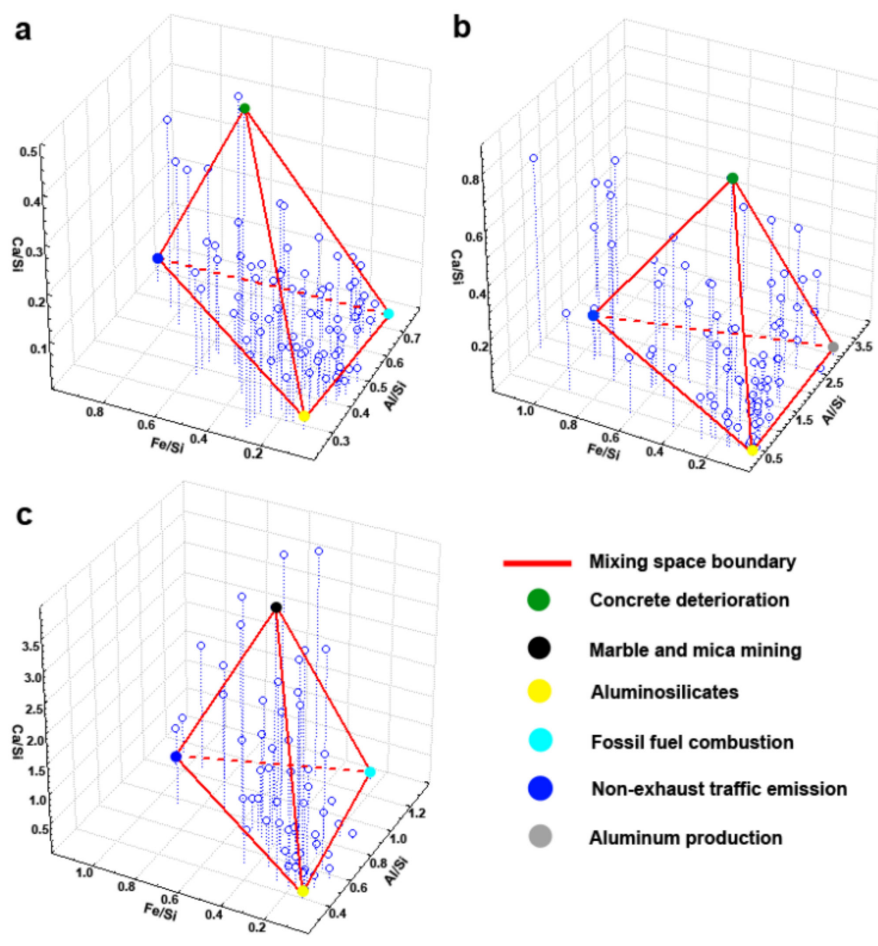

Figure 3. Diagrams illustrating the mixing of PM from different sources in snowpack in Irkutsk (a), Shelekhov (b) and Slyudyanka (c) cities using concentrations of Al, Fe and Ca normalized to concentration of Si as tracers; empty circles are snow samples, colored circles are emission sources. 
Table 3. Values of source tracer ratios.

\begin{tabular}{|c|c|c|c|c|c|c|}
\hline Pollution Source & Si/Al & $\mathrm{Fe} / \mathrm{Al}$ & $\mathrm{Ca} / \mathrm{Al}$ & $\mathrm{Al} / \mathrm{Si}$ & $\mathrm{Fe} / \mathrm{Si}$ & $\mathrm{Ca} / \mathrm{Si}$ \\
\hline & \multicolumn{6}{|c|}{ Irkutsk } \\
\hline Concrete deterioration & 3.25 & 0.91 & 0.54 & 0.59 & 0.55 & 0.45 \\
\hline Non-exhaust traffic emissions & 1.25 & 1.11 & 0.03 & 0.66 & 0.96 & 0.05 \\
\hline Aluminosilicates & 3.65 & 0.33 & 0.14 & 0.28 & 0.10 & 0.03 \\
\hline \multirow[t]{2}{*}{ Fossil fuel combustion } & 1.11 & 0.13 & 0.07 & 0.73 & 0.08 & 0.01 \\
\hline & \multicolumn{6}{|c|}{ Shelekhov } \\
\hline Concrete deterioration & 0.98 & 0.76 & 0.53 & 2.01 & 0.39 & 0.71 \\
\hline Non-exhaust traffic emissions & 1.06 & 0.83 & 0.07 & 1.35 & 0.94 & 0.17 \\
\hline Aluminosilicates & 2.84 & 0.11 & 0.02 & 0.35 & 0.04 & 0.02 \\
\hline \multirow[t]{2}{*}{ Aluminum production } & 0.17 & 0.05 & 0.01 & 3.01 & 0.04 & 0.03 \\
\hline & \multicolumn{6}{|c|}{ Slyudyanka } \\
\hline Marble and mica mining & 2.15 & 0.60 & 6.93 & 0.92 & 0.52 & 3.96 \\
\hline Non-exhaust traffic emissions & 2.18 & 1.54 & 0.18 & 1.03 & 1.06 & 0.12 \\
\hline Aluminosilicates & 3.51 & 0.59 & 0.22 & 0.41 & 0.13 & 0.08 \\
\hline Fossil fuel combustion & 1.74 & 0.14 & 0.09 & 1.32 & 0.25 & 0.09 \\
\hline
\end{tabular}

\subsection{Source Apportionment of Particulate Matter Using End-Member Mixing Approach}

The presence of three tracers $(\mathrm{Si} / \mathrm{Al}, \mathrm{Fe} / \mathrm{Al}, \mathrm{Ca} / \mathrm{Al}$ or $\mathrm{Al} / \mathrm{Si}, \mathrm{Fe} / \mathrm{Si}, \mathrm{Ca} / \mathrm{Si})$ determines the existence of four pollution sources. The contributions of PM sources were calculated using simultaneous equations:

$$
\left\{\begin{array}{c}
f_{1}+f_{2}+f_{3}+f_{4}=1 \\
\mathrm{~T}_{1}^{1} \cdot f_{1}+\mathrm{T}_{2}^{1} \cdot f_{2}+\mathrm{T}_{3}^{1} \cdot f_{3}+\mathrm{T}_{4}^{1} \cdot f_{4}=\mathrm{T}_{\text {mix }}^{1} \\
\mathrm{~T}_{1}^{2} \cdot f_{1}+\mathrm{T}_{2}^{2} \cdot f_{2}+\mathrm{T}_{3}^{2} \cdot f_{3}+\mathrm{T}_{4}^{2} \cdot f_{4}=\mathrm{T}_{\text {mix }}^{2} \\
\mathrm{~T}_{1}^{3} \cdot f_{1}+\mathrm{T}_{2}^{3} \cdot f_{2}+\mathrm{T}_{3}^{3} \cdot f_{3}+\mathrm{T}_{4}^{3} \cdot f_{4}=\mathrm{T}_{\text {mix }}^{3}
\end{array}\right.
$$

where $\mathrm{T}$ is a tracer and $f$ is the contribution of a specified source. Superscripts denote the tracer number, subscripts denote the source (concrete deterioration, non-exhaust traffic emission, silicates etc.) number, and the subscript mix denotes mixture or snow.

3.3.1. Differences in Source Contributions Resulting from the Use of Al-Normalized and Si-Normalized Tracer Ratios

The source contributions obtained using two sets of tracers were different (Table 4). The greatest differences between contributions of respective sources calculated using element concentrations normalized to $\mathrm{Al}$ (Figure 2) and those normalized to Si (Figure 3) were observed for Shelekhov city. Probably, the normalization of concentrations of tracer elements to aluminum obscured the real proportions among the $\mathrm{Ca}$, Fe and $\mathrm{Si}$ in particulate matter because aluminum is definitely pollutant in that area.

The contributions of respective PM sources calculated for Irkutsk city using Al-tracers (Figure 2a) and Si-tracers (Figure 3a) were quite similar. That was due to similar Ca:Fe:Al and $\mathrm{Ca}: \mathrm{Fe}: \mathrm{Si}$ proportions in most part of particulate matter samples. Similar proportions of chemical species resulted in similar positions of sample points relative to PM sources in Figures 2a and 3a.

In Slyudyanka the contributions of marble mining and non-exhaust traffic emission calculated using Al-normalized tracers were similar to contributions of respective sources calculated using Si-normalized tracers. However, the contributions of aluminosilicates and fossil fuel combustion calculated using Al-tracers were different from contributions of respective sources calculated using Si-tracers. This difference was simply due to different sample points in Figures $2 \mathrm{c}$ and $3 \mathrm{c}$ used as fossil fuel combustion sources. The results of calculations using both sets of tracers could be true because higher contribution of fossil fuel combustion with respect to aluminosilicates can be explained by high proportion of private residences, and the higher contribution of aluminosilicates can be explained by the presence of abandoned mica quarry. 
Table 4. Contributions of PM sources to snow pollution in three cities using different tracers, \%.

\begin{tabular}{cccc}
\hline Pollution Source & \multicolumn{3}{c}{ Tracers } \\
& Si, Fe, Ca Normalized to Al Al, Fe, Ca Normalized to Si \\
\hline & 22 & Irkutsk & 20 \\
Concrete deterioration & 3 & & 8 \\
Non-exhaust traffic emissions & 39 & 38 \\
Aluminosilicates & 35 & 34 \\
Fossil fuel combustion & & Shelekhov & 12 \\
& 23 & & 15 \\
Concrete deterioration & 6 & 51 \\
Non-exhaust traffic emissions & 23 & 22 \\
Aluminosilicates & 49 & \\
Aluminum production & & & 18 \\
& 18 & 18 \\
Marble and mica mining & 24 & 53 \\
Non-exhaust traffic emissions & 19 & \\
Aluminosilicates & 38 & \\
Fossil fuel combustion & & \\
\hline
\end{tabular}

Since the $\mathrm{Si}$ is the most abundant naturally-occurring element in the Earth crust (after O), the source contributions obtained using Si-normalized concentrations of $\mathrm{Al}, \mathrm{Fe}$ and $\mathrm{Ca}$ as tracers seem more correct. One more reason supporting this point of view is that the aluminum is definitely the pollutant in Shelekhov city.

\subsubsection{Differences in Contributions of Sources Common for All the Three Cities}

Since it had been established that Si-normalized element concentrations are more suitable tracers than Al-normalized ones only the source contributions obtained using Si-tracers are discussed below. The contributions of sources common for all the three cities such as non-exhaust traffic emission and aluminosilicates increase in row IrkutskShelekhov-Slyudyanka. The increase in contribution of non-exhaust emissions was due to decrease in use of public transportation and increase in use of personal vehicles with decrease in city size. The increase in contribution of aluminosilicates could be due to application of sand instead of salt to deice roads in small cities. The high contributions of non-exhaust traffic emission observed in small cities Shellekhov and Slyudyanka could also be conditioned by the Trans-Siberian Highway passing through these cities. The high contribution of aluminosilicates in Slyudyanka could also be due to deposition of silicate dust blown by the wind from mica and marble quarries.

\subsubsection{Source Attribution of Chemical Species That Were Not Used as Source Tracers}

The most powerful pollution sources in Irkutsk city are aluminosilicates and fossil fuel combustion contributing $38 \%$ and $34 \%$ of particulate matter respectively. Since the aluminosilicates in snowpack are mostly of natural origin, the heavy metals such as $\mathrm{Ti}, \mathrm{Cr}$, $\mathrm{Mn}, \mathrm{Fe}, \mathrm{Cu}, \mathrm{Ni}$ and $\mathrm{Pb}$, of which the concentrations are much higher in Irkutsk than in the other cities, originated from fossil fuel combustion.

The concentrations of heavy metals in snow from Shelekhov were much lower than those in snow from Irkutsk and Slyudyanka, thus most of heavy metals were probably originated from some minor PM sources, like non-exhaust traffic emission or aluminum production, rather than from aluminosilicates that contributed 51\% to snow PM. The high concentration of $\mathrm{Pb}$ may originate from cable production located in Shelekhov city because lead is the material widely used for cable armoring and sheathing. However, some nonexhaust traffic emission sources, like abrasion of wheel weights, may also contribute to high levels of $\mathrm{Pb}$ in snow [66,67].

The contribution of aluminosilicates to snow pollution in Slyudyanka city was at least two and a half times higher than contribution of any other source. Since the aluminosil- 
icates were supposedly of natural origin, the most probable sources of heavy metals in Slyudyanka's snowpack were non-exhaust traffic emission and fossil fuel combustion.

\subsection{Source Apportionment of Particulate Matter Using Positive Matrix Factorization}

The most interpretable result obtained for Irkutsk was rotated $\left(F_{\text {peak }}=0.5\right)$ five-factor solution. The differences between $Q_{\text {true }}$ and $Q_{\text {expected }}$ were less than $16 \%$.

The four-factor PMF solution obtained for Shelekhov was very stable $\left(\mathrm{Q}_{\text {true }} / \mathrm{Q}_{\text {expected }}=1.3\right)$ and the factor mass fractions did not change with varying $F_{\text {peak }}$. The results of the diagnostic tools offered by EPA PMF revealed that both solutions were robust with low rotational ambiguity. Bootstrap results indicated that the factors were reproduced at a minimum level of $85 \%$ of the produced resamples, while displacement and bootstrap-displacement showed no factor swaps for the minimum dQ level [46].

The rotated $\left(\mathrm{F}_{\text {peak }}=1\right)$ three-factor solution obtained for Slyudyanka was the most uncertain. The differences between $Q_{\text {true }}$ and $Q_{\text {expected }}$ were high enough (30-40\%). Despite this, the three-component solution was the most clearly interpretable solution among others. The uncertainty in PMF solution for Slyudyanka was probably due to chemical transformations of source fingerprints [68] like dissolution of carbonate particles due to freezing-thawing or their reactions with dissolved meltwater components. Error could also arise from weak or sporadic sources like, for example, residential furnaces that use different fuels of different origin and cannot be represented by dedicated factors.

\subsubsection{PM Sources Identified in Irkutsk City and Their Contributions to Snow Pollution}

Five factors obtained for Irkutsk contributed 19\%, 27\%, 20\%, 16\% and $18 \%$ of chemical materials to snow PM, respectively (Figure 4). Factor 1 was characterized by the relatively high concentrations of $\mathrm{Al}$, Ti and Fe; however, the factor's contribution to concentrations of these elements is low. The $\mathrm{Al}, \mathrm{Ti}$ and Fe could originate either from non-exhaust traffic emission or fossil fuel combustion; however, the quite low value of $\mathrm{Si} / \mathrm{Al}$ ratio argue in favor of combustion of fuel oil [40]. The contribution of Factor 1 to concentrations of Cr, $\mathrm{Ni}, \mathrm{Cu}$ and $\mathrm{Pb}$ was highest among the other factors that also argues in favor of pyrogenic origin of those metals. Factor 2 was characterized by highest concentrations of Si and Al as well as the highest contributions to $\mathrm{Si}$ and $\mathrm{Al}$ concentrations among all factors. It was supposed that this factor represented aluminosilicates because the value of $\mathrm{Si} / \mathrm{Al}$ ratio was equal to 4 that is typical for aluminosilicates (Table 3). The concentrations of heavy metals in this factor as well as the factor's contributions to metal concentrations were quite low.

Factor 3 was ascribed to concrete deterioration because it was characterized by high contributions of Ca and Sr (up to 90\%) to snow PM. Being the geochemical analogue of calcium, $\mathrm{Sr}$ isomorphically substitutes $\mathrm{Ca}$ in most minerals, especially in carbonates. Thus, the concentrations of $\mathrm{Ca}$ and $\mathrm{Sr}$ are always proportional to each other. The high concentration of $\mathrm{Si}$ also testifies to lithogenic origin of PM associated with this factor. Factor 4 was identified as biomass combustion and characterized by high concentration of K [69]. The contribution of Factor 4 to concentrations of most of chemical species was quite low. Factor 5 was relevant to non-exhaust traffic emission and characterized by high concentrations of $\mathrm{Si}, \mathrm{K}, \mathrm{Ca}$, Ti and high contributions of $\mathrm{K}, \mathrm{Ti}, \mathrm{Cr}, \mathrm{Mn}, \mathrm{Fe}$. The $\mathrm{Si}$ and $\mathrm{Ca}$ were probably originated from deterioration of road pavement and curb, whereas $\mathrm{K}$, $\mathrm{Ti}, \mathrm{Cr}, \mathrm{Mn}$ and Fe came from brake pads and disks. For example, it is known that the concentrations of $\mathrm{K}$ (that is usually considered as biogenic element) in car brake dust may reach $0.5 \%$ [59]. However, most probably the high contribution of $\mathrm{K}$ may indicate some mixing with other sources like biomass combustion. 

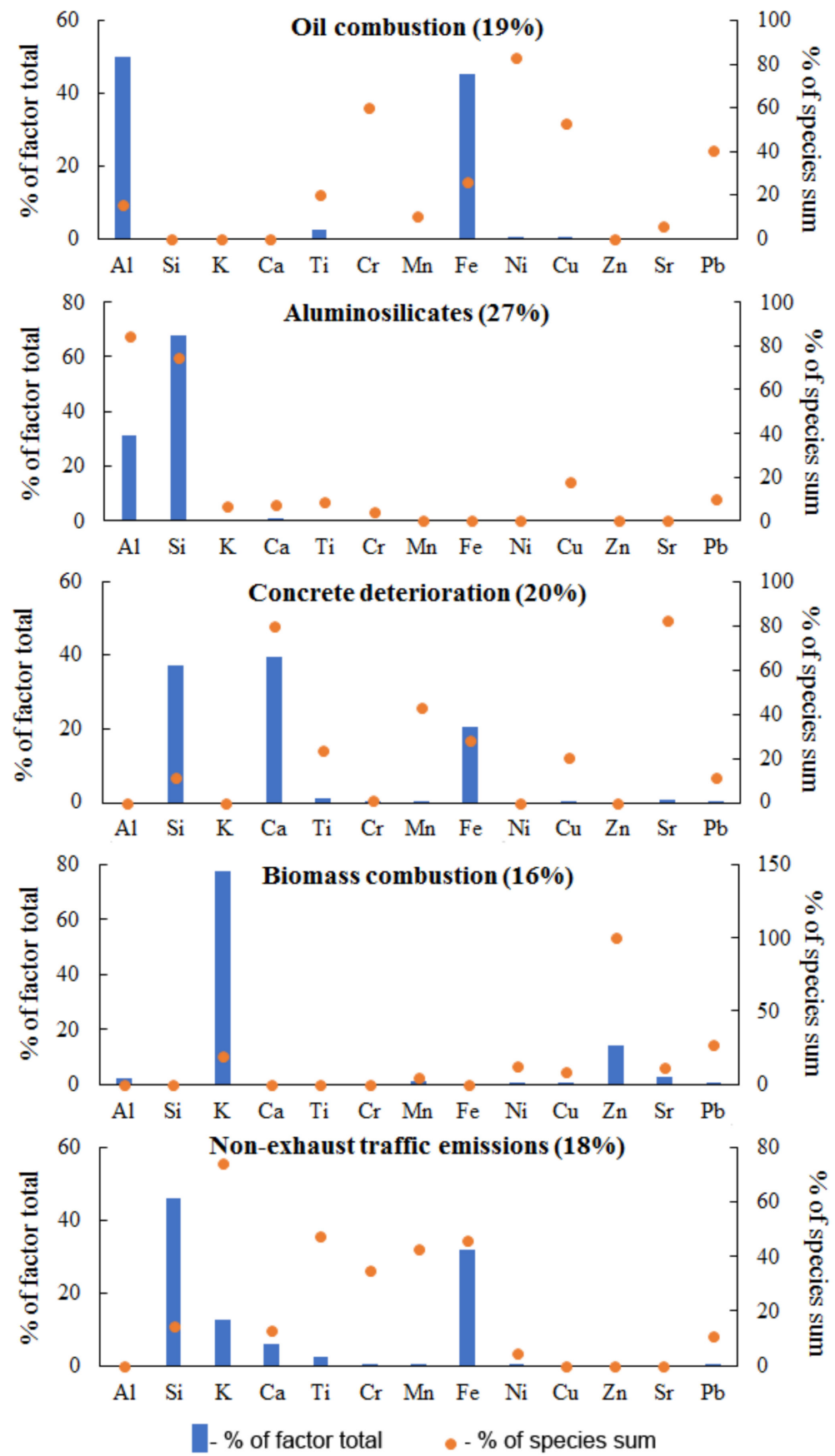

Figure 4. Source profiles obtained by PMF analysis of snow particulate matter from Irkutsk.

3.4.2. PM Sources Identified in Shelekhov City and Their Contributions to Snow Pollution

In Shelekhov city four factors were identified (Figure 5).

Compositions of three of these factors, namely non-exhaust traffic emissions, concrete deterioration and aluminosilicates, were similar to those identified in Irkutsk. These factors contributed $24 \%, 22 \%$ and $24 \%$ of chemical materials to snow PM, respectively. The fourth factor, characterized by extreme concentration of $\mathrm{Al}(90 \%)$ and high contribution of $\mathrm{Al}$ $(79 \%)$ to PM, was identified as aluminum production (Figure 5). This factor contributed $30 \%$ to PM.

The profiles of non-exhaust traffic emissions, concrete deterioration and aluminosilicates identified in Shelekhov and Irkutsk were characterized by different concentrations of heavy metals. For example, in Irkutsk the contribution of non-exhaust traffic emissions 
to concentrations of $\mathrm{Cu}, \mathrm{Zn}$ and $\mathrm{Sr}$ in PM was equal to zero, whereas in Shelekhov the contribution of this factor to concentrations of respective elements was high enough. The same is also true for concrete deterioration and aluminosilicates. The profiles of these sources obtained for Irkutsk are characterized by much lower contributions of $\mathrm{Mn}, \mathrm{Fe}$, $\mathrm{Ni}, \mathrm{Zn}$ and $\mathrm{Sr}$ with respect to that obtained for Shelekhov. One more difference between concrete profiles is much higher concentration of $\mathrm{Si}$ in Irkutsk.
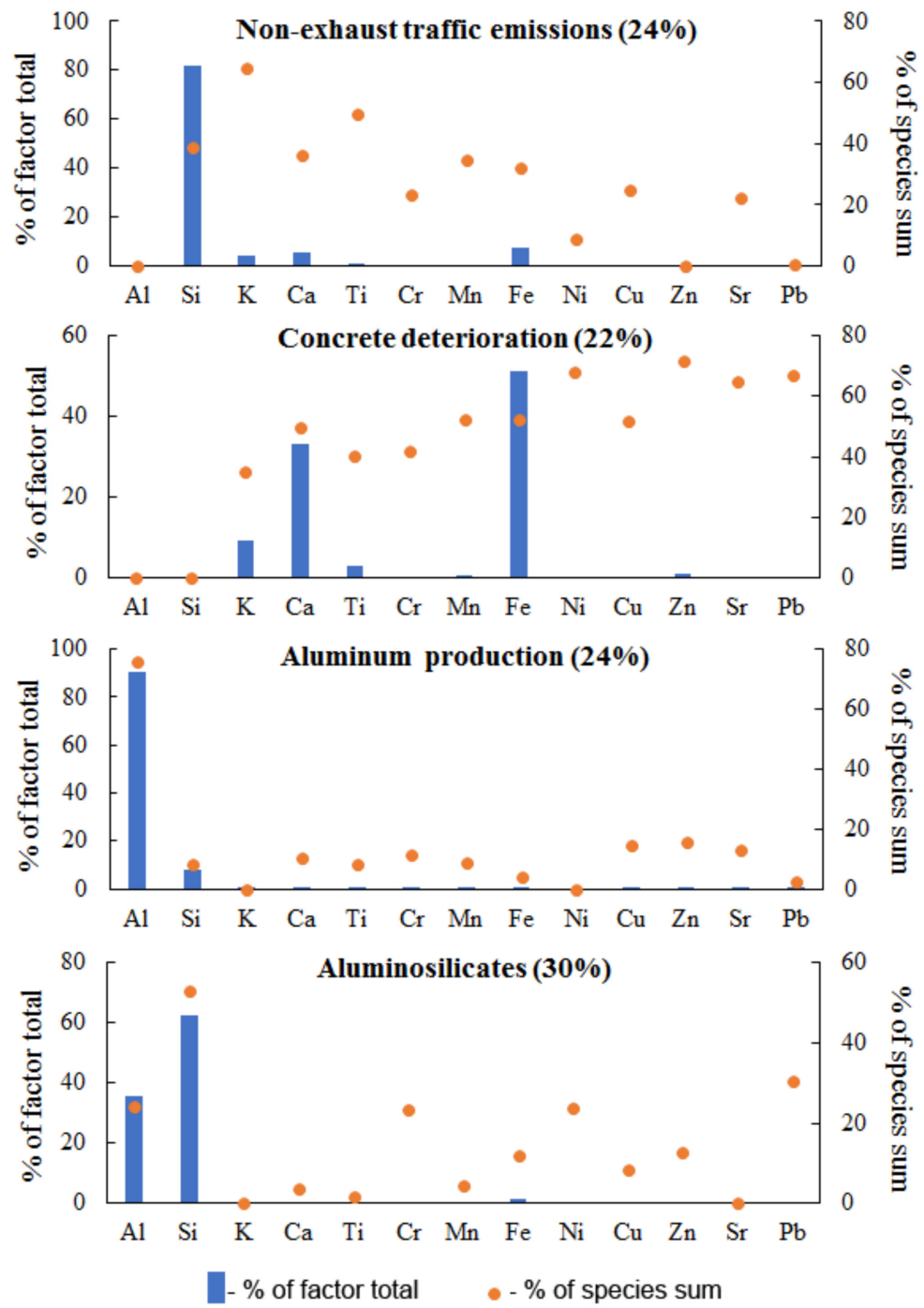

Figure 5. Source profiles obtained by PMF analysis of snow particulate matter from Shelekhov.

3.4.3. PM Sources Identified in Slyudyanka City and Their Contributions to Snow Pollution

Three factors were identified in Slyudyanka (Figure 6): Fossil fuel combustion combined with non-exhaust traffic emissions, aluminosilicates and marble/mica mining combined with concrete deterioration. These factors contributed $25 \%, 45 \%$ and $27 \%$ of chemical materials to snow PM, respectively. Combining the profiles of fossil fuel combustion and non-exhaust traffic emissions by PMF was caused by similar concentrations of $\mathrm{Al}$ and Fe in these two sources. The mining and concrete deterioration were also combined by PMF due to similarity between profiles of mining wastes stored in abandoned quarries and aluminosilicates contained in concrete used for constructing pavements, footpaths and buildings. Probably, mining wastes were used as the component of concrete. The composition of aluminosilicates identified in Slyudyanka was similar to composition of aluminosilicates identified in Irkutsk and Shelekhov. 

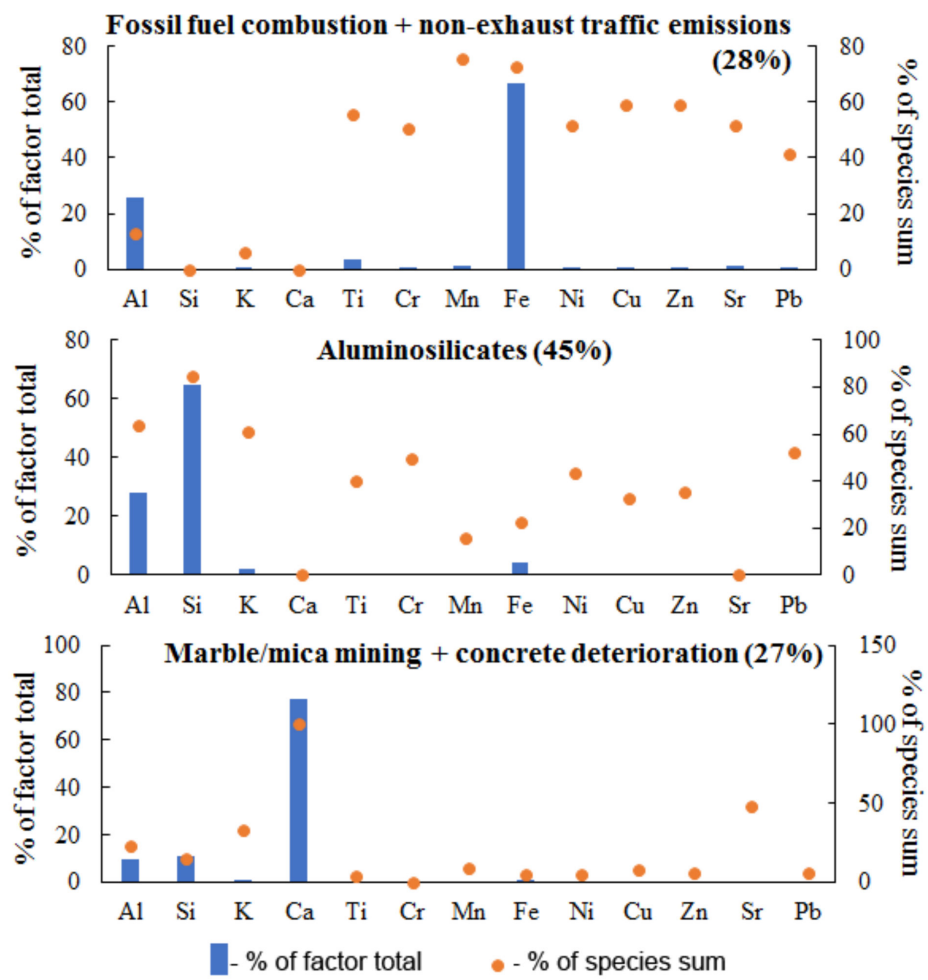

Figure 6. Source profiles obtained by PMF analysis of snow particulate matter from Slyudyanka.

\section{Conclusions}

The results obtained using EMMA and PMF demonstrated the importance of simultaneous use of different source apportionment techniques for determining the number of PM sources and their contributions to air pollution. The main conclusions reached in this study are as follows:

1. In urban environments of Eastern Siberia, the most suitable tracers of PM sources are $\mathrm{Si}, \mathrm{Al}, \mathrm{Fe}$ and $\mathrm{Ca}$. It was found that $\mathrm{Si}, \mathrm{Fe}$ and $\mathrm{Ca}$ were the tracers of aluminosilicates, non-exhaust traffic emissions and concrete deterioration, respectively. Aluminum was found to be the tracer of both fossil fuel combustion and aluminum production. The trace elements measured in PM was not attributed to any particular source and thus could not be used as source tracers.

2. The number of sources identified in each city using EMMA was equal to four, whereas the number of sources identified in Irkutsk, Shelekhov and Slyudyanka using PMF model was equal to five, four and three, respectively. Some sources identified using PMF were the combinations of two sources identified using EMMA, whereas some sources identified using EMMA were split by PMF into two sources. Despite of this, the types of pollution sources identified in each particular city using EMMA and PMF model were the same.

3. The contributions of combined sources identified using PMF are similar to sums of contributions of respective single sources identified using EMMA. Moreover, the contributions of point PM sources such as aluminum production (Shelekhov) and marble quarry (Slyudyanka) evaluated using EMMA and PMF were quite similar.

4. Despite the differences in number of PM sources and their contributions, the data obtained using both techniques are in agreement with existing knowledge on economicgeographical situations in studied cities. For example, the contributions of nonexhaust traffic emission and aluminosilicates calculated using both techniques increase with decrease of city size, due to increase in use of personal vehicles and application of local deicing materials (sand, gravel) instead of salt. 
Author Contributions: Research design, map drawings, data analysis and writing, M.Y.S.; chemical analyses, N.A.O. and O.G.N.; supervision and project administration, T.V.K. All authors have read and agreed to the published version of the manuscript.

Funding: This work was supported by the Russian Academy of Sciences, Government contract No. 0279-2021-0014 (121032300199-9).

Institutional Review Board Statement: Not applicable.

Informed Consent Statement: Not applicable.

Data Availability Statement: Data available on request from the authors.

Conflicts of Interest: The authors declare no conflict of interest.

\section{References}

1. Mar, T.F.; Norris, G.A.; Koenig, J.Q.; Larson, T.V. Associations between air pollution and mortality in Phoenix, 1995-1997. Environ. Health Perspect. 2000, 108, 347-353. [CrossRef]

2. Tsiouri, V.; Kakosimos, K.E.; Kumar, P. Concentrations, sources and exposure risks associated with particulate matter in the Middle East Area-A review. Air Qual. Atmos. Health 2014, 8, 67-80. [CrossRef]

3. Bartels, S.F.; Gendreau-Berthiaume, B.; Macdonald, S.E. The impact of atmospheric acid deposition on tree growth and forest understory vegetation in the Athabasca Oil Sands Region. Sci. Total Environ. 2019, 696, 133877. [CrossRef]

4. Tranvik, L.J. Acidification of inland waters. AMBIO 2020, 50, 261-265. [CrossRef] [PubMed]

5. Meili, M.; Bishop, K.; Bringmark, L.; Johansson, K.; Munthe, J.; Sverdrup, H.; de Vries, W. Critical levels of atmospheric pollution: Criteria and concepts for operational modelling of mercury in forest and lake ecosystems. Sci. Total Environ. 2003, 304, 83-106. [CrossRef]

6. Bergkvist, B.; Folkeson, L.; Berggren, D. Fluxes of $\mathrm{Cu}, \mathrm{Zn}, \mathrm{Pb}, \mathrm{Cd}, \mathrm{Cr}$, and $\mathrm{Ni}$ in temperate forest ecosystems. Water Air Soil Pollut. 1989, 47, 217-286. [CrossRef]

7. Semenov, M.; Bashkin, V.; Sverdrup, H. Critical Loads of Acidity for Forest Ecosystems of North Asia. Water Air Soil Pollut. 2001, 130, 1193-1198. [CrossRef]

8. Semenov, M.; Semenov, Y.; Silaev, A.; Begunova, L. Source Apportionment of Inorganic Solutes in Surface Waters of Lake Baikal Watershed. Sustainability 2021, 13, 5389. [CrossRef]

9. Chen, L.; Zhi, X.; Shen, Z.; Dai, Y.; Aini, G. Comparison between snowmelt-runoff and rainfall-runoff nonpoint source pollution in a typical urban catchment in Beijing, China. Environ. Sci. Pollut. Res. 2018, 25, 2377-2388. [CrossRef]

10. Lafrenière, M.J.; Blais, J.M.; Sharp, M.J.; Schindler, D.W. Organochlorine Pesticide and Polychlorinated Biphenyl Concentrations in Snow, Snowmelt, and Runoff at Bow Lake, Alberta. Environ. Sci. Technol. 2006, 40, 4909-4915. [CrossRef] [PubMed]

11. Vijayan, A.; Österlund, H.; Marsalek, J.; Viklander, M. Laboratory Melting of Late-Winter Urban Snow Samples: The Magnitude and Dynamics of Releases of Heavy Metals and PAHs. Water Air Soil Pollut. 2019, 230, 182. [CrossRef]

12. Semenov, M.Y.; Marinaite, I.I. Multi-source apportionment of polycyclic aromatic hydrocarbons using end-member mixing approach. Environ. Earth Sci. 2014, 73, 1769-1777. [CrossRef]

13. Popovicheva, O.; Molozhnikova, E.; Nasonov, S.; Potemkin, V.; Penner, I.; Klemasheva, M.; Marinaite, I.; Golobokova, L.; Vratolis, S.; Eleftheriadis, K.; et al. Industrial and wildfire aerosol pollution over world heritage Lake Baikal. J. Environ. Sci. 2021, 107, 49-64. [CrossRef] [PubMed]

14. Zhamsueva, G.; Zayakhanov, A.; Tcydypov, V.; Dementeva, A.; Balzhanov, T. Spatial-Temporal Variability of Small Gas Impurities over Lake Baikal during the Forest Fires in the Summer of 2019. Atmosphere 2020, 12, 20. [CrossRef]

15. Semenov, M.Y.; Marinaite, I.I. Using the end-member mixing approach to apportion sources of polycyclic aromatic hydrocarbons in various environmental compartments. Environ. Earth Sci. 2016, 75, 207. [CrossRef]

16. Semenov, M.Y.; Marinaite, I.I.; Golobokova, L.P.; Khuriganova, O.I.; Khodzher, T.V.; Semenov, Y.M. Source apportionment of polycyclic aromatic hydrocarbons in Lake Baikal water and adjacent air layer. Chem. Ecol. 2017, 33, 977-990. [CrossRef]

17. Semenov, M.Y.; Marinaite, I.I.; Zhuchenko, N.A.; Silaev, A.V.; Vershinin, K.E.; Semenov, Y.M. Revealing the factors affecting occurrence and distribution of polycyclic aromatic hydrocarbons in water and sediments of Lake Baikal and its tributaries. Chem. Ecol. 2018, 34, 925-940. [CrossRef]

18. Thurston, G.D.; Ito, K.; Lall, R. A source apportionment of U.S. fine particulate matter air pollution. Atmos. Environ. 2011, 45, 3924-3936. [CrossRef] [PubMed]

19. Song, Y.; Xie, S.; Zhang, Y.; Zeng, L.; Salmon, L.G.; Zheng, M. Source apportionment of PM2.5 in Beijing using principal component analysis/absolute principal component scores and UNMIX. Sci. Total Environ. 2006, 372, 278-286. [CrossRef]

20. Beddows, D.C.S.; Dall'Osto, M.; Harrison, R.M. Cluster analysis of rural, urban and curbside 916 atmospheric particle size data. Environ. Sci. Technol. 2009, 43, 4694-4700. [CrossRef] [PubMed]

21. Chen, L.; Qi, X.; Nie, W.; Wang, J.; Xu, Z.; Wang, T.; Liu, Y.; Shen, Y.; Xu, Z.; Kokkonen, T.V.; et al. Cluster analysis of submicron particle number size distributions at the SORPES station in the Yangtze River Delta of East China. J. Geophys. Res. Atmos. 2021, 126, e2020JD034004. [CrossRef] 
22. Wan, X.; Chen, J.; Tian, F.; Sun, W.; Yang, F.; Saiki, K. Source apportionment of PAHs in atmospheric particulates of Dalian: Factor analysis with nonnegative constraints and emission inventory analysis. Atmos. Environ. 2006, 40, 6666-6675. [CrossRef]

23. Hu, N.-J.; Huang, P.; Liu, J.-H.; Ma, D.-Y.; Shi, X.-F.; Mao, J.; Liu, Y. Characterization and source apportionment of polycyclic aromatic hydrocarbons (PAHs) in sediments in the Yellow River Estuary, China. Environ. Earth Sci. 2014, 71, 873-883. [CrossRef]

24. Larsen, R.K.; Baker, J. Source Apportionment of Polycyclic Aromatic Hydrocarbons in the Urban Atmosphere: A Comparison of Three Methods. Environ. Sci. Technol. 2003, 37, 1873-1881. [CrossRef]

25. Cai, K.; Li, C. Street Dust Heavy Metal Pollution Source Apportionment and Sustainable Management in A Typical CityShijiazhuang, China. Int. J. Environ. Res. Public Health 2019, 16, 2625. [CrossRef]

26. Song, Y.; Li, H.; Li, J.; Mao, C.; Ji, J.; Yuan, X.; Li, T.; Ayoko, G.; Frost, R.L.; Feng, Y.-X. Multivariate linear regression model for source apportionment and health risk assessment of heavy metals from different environmental media. Ecotoxicol. Environ. Saf. 2018, 165, 555-563. [CrossRef]

27. Henry, R.C. Multivariate receptor modeling by N-dimensional edge detection. Chemom. Intell. Lab. Syst. 2003, 65, 179-189. [CrossRef]

28. Paatero, P.; Tapper, U. Positive matrix factorization: A non-negative factor model with optimal utilization of error estimates of data values. Environmetrics 1994, 5, 111-126. [CrossRef]

29. Belis, C.; Favez, O.; Mircea, M.; Diapouli, E.; Manousakas, M.; Vratolis, S.; Gilardoni, S.; Paglione, M.; Decesari, S.; Mocnik, G.; et al. European Guide on Air Pollution Source Apportionment with Receptor Models; Publications Office of the European Union: Luxembourg, 2019; ISBN 978-92-76-09001-4. [CrossRef]

30. Gietl, J.K.; Klemm, O. Source Identification of Size-Segregated Aerosol in Münster, Germany, by Factor Analysis. Aerosol Sci. Technol. 2009, 43, 828-837. [CrossRef]

31. Wang, Y.; Zhuang, G.; Tang, A.; Yuan, H.; Sun, Y.; Chen, S.; Zheng, A. The ion chemistry and the source of PM2.5 aerosol in Beijing. Atmos. Environ. 2005, 39, 3771-3784. [CrossRef]

32. Ulbrich, I.M.; Canagaratna, M.R.; Zhang, Q.; Worsnop, D.R.; Jimenez, J.L. Interpretation of organic components from Positive Matrix Factorization of aerosol mass spectrometric data. Atmos. Chem. Phys. Discuss. 2009, 9, 2891-2918. [CrossRef]

33. Shah, R.U.; Robinson, E.S.; Gu, P.; Robinson, A.L.; Apte, J.S.; Presto, A.A. High-spatial-resolution mapping and source apportionment of aerosol composition in Oakland, California, using mobile aerosol mass spectrometry. Atmos. Chem. Phys. Discuss. 2018, 18, 16325-16344. [CrossRef]

34. Pindado, O.; Perez, R.M. Source apportionment of particulate organic compounds in a rural area of Spain by positive matrix factorization. Atmos. Pollut. Res. 2011, 2, 492-505. [CrossRef]

35. Simoneit, B.R. Biomass burning-A review of organic tracers for smoke from incomplete combustion. Appl. Geochem. 2002, 17, 129-162. [CrossRef]

36. Lucarelli, F.; Calzolai, G.; Chiari, M.; Giardi, F.; Czelusniak, C.; Nava, S. Hourly Elemental Composition and Source Identification by Positive Matrix Factorization (PMF) of Fine and Coarse Particulate Matter in the High Polluted Industrial Area of Taranto (Italy). Atmosphere 2020, 11, 419. [CrossRef]

37. Acciai, C.; Zhang, Z.; Wang, F.; Zhong, Z.; Lonati, G. Characteristics and source Analysis of trace Elements in PM2.5 in the Urban Atmosphere of Wuhan in Spring. Aerosol Air Qual. Res. 2017, 17, 2224-2234. [CrossRef]

38. Krecl, P.; Larsson, E.H.; Ström, J.; Johansson, C. Contribution of residential wood combustion and other sources to hourly winter aerosol in Northern Sweden determined by positive matrix factorization. Atmos. Chem. Phys. Discuss. 2008, 8, $3639-3653$. [CrossRef]

39. Semenov, M.Y.; Marinaite, I.I.; Bashenkhaeva, N.V.; Zhuchenko, N.A.; Khuriganova, O.I.; Molozhnikova, E.V. Polycyclic aromatic hydrocarbons in a small eastern siberian river: Sources, delivery pathways, and behavior. Environ. Earth Sci. 2016, 75, 954. [CrossRef]

40. Semenov, M.Y.; Silaev, A.V.; Semenov, Y.M.; Begunova, L.A. Using Si, Al and Fe as Tracers for Source Apportionment of Air Pollutants in Lake Baikal Snowpack. Sustainability 2020, 12, 3392. [CrossRef]

41. Tian, Y.; Xiao, Z.; Wang, H.; Peng, X.; Guan, L.; Huangfu, Y.; Shi, G.; Chen, K.; Bi, X.; Feng, Y. Influence of the sampling period and time resolution on the PM source apportionment: Study based on the high time-resolution data and long-term daily data. Atmos. Environ. 2017, 165, 301-309. [CrossRef]

42. Luo, H.; Guan, Q.; Lin, J.; Wang, Q.; Yang, L.; Tan, Z.; Wang, N. Air pollution characteristics and human health risks in key cities of northwest China. J. Environ. Manag. 2020, 269, 110791. [CrossRef] [PubMed]

43. Javed, W.; Guo, B. Chemical characterization and source apportionment of fine and coarse atmospheric particulate matter in Doha, Qatar. Atmos. Pollut. Res. 2020, 12, 122-136. [CrossRef]

44. Pan, Y.; Liu, J.; Zhang, L.; Cao, J.; Hu, J.; Tian, S.; Li, X.; Xu, W. Bulk Deposition and Source Apportionment of Atmospheric Heavy Metals and Metalloids in Agricultural Areas of Rural Beijing during 2016-2020. Atmosphere 2021, 12, 283. [CrossRef]

45. Betsou, C.; Diapouli, E.; Tsakiri, E.; Papadopoulou, L.; Frontasyeva, M.; Eleftheriadis, K.; Ioannidou, A. First-Time Source Apportionment Analysis of Deposited Particulate Matter from a Moss Biomonitoring Study in Northern Greece. Atmosphere 2021, 12, 208. [CrossRef]

46. Manousakas, M.I.; Florou, K.; Pandis, S.N. Source Apportionment of Fine Organic and Inorganic Atmospheric Aerosol in an Urban Background Area in Greece. Atmosphere 2020, 11, 330. [CrossRef] 
47. Wang, F.; Yu, H.; Wang, Z.; Liang, W.; Shi, G.; Gao, J.; Li, M.; Feng, Y. Review of online source apportionment research based on observation for ambient particulate matter. Sci. Total Environ. 2020, 762, 144095. [CrossRef]

48. Christophersen, N.; Neal, C.; Hooper, R.P.; Vogt, R.D.; Andersen, S. Modelling streamwater chemistry as a mixture of soilwater end-members-A step towards second-generation acidification models. J. Hydrol. 1990, 116, 307-320. [CrossRef]

49. Semenov, M.Y.; Zimnik, E.A. A three-component hydrograph separation based on relationship between organic and inorganic component concentrations: A case study in Eastern Siberia, Russia. Environ. Earth Sci. 2014, 73, 611-620. [CrossRef]

50. Shevchenko, V.; Vorobyev, S.; Krickov, I.; Boev, A.; Lim, A.; Novigatsky, A.; Starodymova, D.; Pokrovsky, O. Insoluble Particles in the Snowpack of the Ob River Basin (Western Siberia) a $2800 \mathrm{~km}$ Submeridional Profile. Atmosphere 2020, 11, 1184. [CrossRef]

51. Liang, S.X.; Wu, H.; Sun, H.W. Determination of trace elements in airborne PM10 by inductively coupled plasma mass spectrometry. Int. J. Environ. Sci. Technol. 2015, 12, 1373-1378. [CrossRef]

52. Zhou, X.; Li, Z.; Zhang, T.; Wang, F.; Tao, Y.; Zhang, X.; Wang, F.; Huang, J.; Cheng, T.; Jiang, H.; et al. Chemical nature and predominant sources of PM10 and PM2.5 from multiple sites on the Silk Road, Northwest China. Atmos. Pollut. Res. 2020, 12, 425-436. [CrossRef]

53. Liu, Y.; Yamanaka, T. Tracing groundwater recharge sources in a mountain-plain transitional area using stable isotopes and hydrochemistry. J. Hydrol. 2012, 464-465, 116-126. [CrossRef]

54. Li, T.; Sun, G.; Ma, S.; Liang, K.; Yang, C.; Li, B.; Luo, W. Inferring sources of polycyclic aromatic hydrocarbons (PAHs) in sediments from the western Taiwan Strait through end-member mixing analysis. Mar. Pollut. Bull. 2016, 112, 166-176. [CrossRef] [PubMed]

55. Funk, B.; Göhler, D.; Sachsenhauser, B.; Stintz, M.; Stahlmecke, B.; Johnson, B.A.; Wohlleben, W. Impact of freeze-thaw weathering on integrity, internal structure and particle release from micro- and nanostructured cement composites. Environ. Sci. Nano 2019, 6, 1443-1456. [CrossRef]

56. Estokova, A.; Oravec, J.; Kovalcikova, M. Environmental impact assessment of the concrete composites in terms of the selected toxic metals leaching. Chem. Eng. Trans. 2015, 43, 1915-1920. [CrossRef]

57. Aleksandrova, A.Y.; Timofeeva, S.S. Assessment of the Impact of Mining Enterprises on the State of Atmospheric Air on the Results of Geochemical Snow Surveys. IOP Conf. Ser. Earth Environ. Sci. 2019, 272, 022068. [CrossRef]

58. Westerlund, K.G.; Johansson, C. Emission of metals and particulate matter due to wear of brake linings in Stockholm. Air Poll. 2002, 10, 793-802. [CrossRef]

59. Thorpe, A.; Harrison, R.M. Sources and properties of non-exhaust particulate matter from road traffic: A review. Sci. Total Environ. 2008, 400, 270-282. [CrossRef] [PubMed]

60. Bagi, S.; Sharma, V.; Patel, M.; Aswath, P.B. Effects of diesel soot composition and accumulated vehicle mileage on soot oxidation characteristics. Energy Fuels 2016, 30, 8479-8490. [CrossRef]

61. Popovicheva, O.B.; Kireeva, E.D.; Steiner, S.; Rothen-Rutishauser, B.; Persiantseva, N.M.; Timofeev, M.A.; Shonija, N.K.; Comte, P.; Czerwinski, J. Microstructure and Chemical Composition of Diesel and Biodiesel Particle Exhaust. Aerosol Air Qual. Res. 2014, 14, 1392-1401. [CrossRef]

62. Davydova, N.D.; Znamenskaya, T.I.; Lopatkin, D.A. Identification of chemical elements as pollutants and their primary distribution in steppes of the southern Minusinsk depression. Contemp. Probl. Ecol. 2013, 6, 228-235. [CrossRef]

63. Grebenshchikova, V.I.; Kuzmin, M.I.; Rukavishnikov, V.S.; Efimova, N.V.; Donskikh, I.V.; Doroshkov, A.A. Chemical Contamination of Soil on Urban Territories with Aluminum Production in the Baikal Region, Russia. Air Soil Water Res. 2021, 14, 1-11. [CrossRef]

64. Kvande, H.; Drabløs, P.A. The Aluminum Smelting Process and Innovative Alternative Technologies. J. Occup. Environ. Med. 2014, 56, S23-S32. [CrossRef] [PubMed]

65. Aarhaug, T.A.; Ratvik, A.P. Aluminium Primary Production Off-Gas Composition and Emissions: An Overview. JOM 2019, 71, 2966-2977. [CrossRef]

66. Root, R.A. Analysis of a Study of Lead Wheel Weight Deposition and Abrasion in New Jersey. Water Air Soil Pollut. 2015, $226,381$. [CrossRef]

67. Taylor, M.; Kruger, N. Tyre Weights an Overlooked Diffuse Source of Lead and Antimony to Road Runoff. Sustainability 2020, 12, 6790. [CrossRef]

68. Paatero, P.; Eberly, S.; Brown, S.G.; Norris, G.A. Methods for estimating uncertainty in factor analytic solutions. Atmos. Meas. Tech. 2014, 7, 781-797. [CrossRef]

69. Pachon, J.E.; Weber, R.J.; Zhang, X.; Mulholland, J.A.; Russell, A.G. Revising the use of potassium (K) in the source apportionment of PM2.5. Atmos. Pollut. Res. 2013, 4, 14-21. [CrossRef] 